\title{
PEMILIHAN SMARTPHONE TERBAIK PENUNJANG KEGIATAN AKADEMIS MENGGUNAKAN METODE B WM DAN PENGEMBANGAN AHP
}

\author{
Mochammad Iffan Zulfianri ${ }^{1 *}$, Hasbi Yasin², Sudarno ${ }^{3}$ \\ 1,2,3 Departemen Statistika, Fakultas Sains dan Matematika, Universitas Diponegoro \\ *email: moch.iffan@student.undip.ac.id
}

\begin{abstract}
Multi-Criteria Decision Making (MCDM) is a decision-making method to determine the best alternative from several alternatives based on several certain criteria. One of the alternative decision-making methods that can be used is the Best Worst Method (BWM) and the Analytical Hierarchy Process (AHP). BWM makes structured pairwise comparisons and AHP breaks down complexproblems into hierarchical structures. One of the decisionmaking problems that can be solved by the BWM and AHP methods is the problem of choosing a smartphone. Smartphones are one of the most widely used Information and Communication Technology (ICT) devices by Indonesians. The use of smartphones as ICT devices has benefits for the academic community, especially as a means of supporting academic activities. However, various types and mereks of smartphones are circulating, making users confused about choosing the best smartphone according to their needs. Therefore, a reliable method is needed to make it easier for users to choose the best smartphone, especially in supporting academic activities, namely by using a combination of the BWM method and AHP development. The BWM method is used to calculate the optimal weight of the criteria and the AHP method that has been developed is used to calculate the alternative optimal weight based on the criteria. The combination of the two is used to calcula te the final optimal weight for each alternative. The results of the calculation of the optimal weight of the criteria show that the RAM criterion has the highest weight, which is 0.290 and the Screen Size criterion has the lowest weight, which is 0.047 . The final result obtained is a smartphone type OPPO Find X2 with a final optimal weight of 0.153 to be the best alternative among other alternatives .
\end{abstract}

Keywords: Multi-Criteria Decision Making (MCDM), Best Worst Method (BWM), Analytical Hierarchy Process (AHP), Information and Communic ation Technology (ICT), Smartphones, Academic Activities

\section{PENDAHULUAN}

Ilmu pengetahuan dan teknologi terus berkembang, bahkan dewasa ini berlangsung dengan pesat. Teknologi Informasi dan komunikasi (TIK) juga sedang berkembang sangat pesat terutama pada era globalisasi saat ini. Menurut Munir (2009), TIK secara umum merangkum keseluruhan aspek yang berkaitan dengan mesin (komputer dan telekomunikasi) dan metode yang diterapkan untuk mengumpulkan, menyimpan, dan menyampaikan suatu informasi. Salah satu perangkat TIK yang paling banyak digunakan saat ini adalah smartphone.

Menurut Eriksson (2017) definisi dari smartphone adalah telepon genggam dengan tampilan layar sentuh yang memungkinkan akses ke layanan berbasis internet tingkat lanut dan mampu melakukan banyak fungsi dari komputer, yakni memiliki sistem operasi yang dapat mengunduh serta menjalankan beragam aplikasi termasuk aplikasi yang dibuat oleh pengembang pihak ketiga.

Penggunaan smartphone sangat bermanfaat dalam membantu khususnya bagi para akademisi yang mempunyai banyak kebutuhan informasi. Mahasiswa adalah salah satu kelompok civitas akademik yang paling banyak menggunakan smartphone sebagai media untuk mengakses informasi secara mudah dan cepat guna untuk pemenuhan informasi. Smartphone 
dapat digunakan sebagai sarana pembelajaran yakni melalui smartphone seseorang dapat mempelajari hal-hal baru melalui isi atau pesan yang disalurkan.

Dengan berbagai macam tipe dan merk smartphone yang beredar, pengguna semakin bingung menentukan pilihan dalam memilih produk Smartphone sesuai dengan kebutuhan. Dalam konteks penelitian ini, fitur dan kriteria tersebut diselaraskan fungsinya dalam menunjang kegiatan akademik. Oleh sebab itu, dibutuhkan sebuah metode yang andal agar dapat membantu menentukan pemilihan smartphone terbaik berdasarkan spesifikasi, fitur dan kriteria yang ada dalam menunjang kegiatan akademik. Salah satu alternatif metode yang dapat digunakan adalah metode Best Worst Method (BWM) dan Analytical Hierarchy Process (AHP).

Metode BWM membuat perbandingan secara terstruktur dan metode AHP menghitung bobot dengan sturktur hirarki sehingga proses perhitungan rinci dari kriteria sampai sub-kriteria serta memperhitungkan validitas sampai dengan batas toleransi inkonsistensi. Perpaduan keduanya menjadikan hasil akhir pembobotan yang mampu diandalkan dan dipertanggungjawabkan karena melalui proses perhitungan yang komprehensif.

Tujuan dari penelitian ini adalah untuk menggambarkan penggunaan metode pengambilan keputusan BWM dan pengembangan AHP serta perpaduan kedua metode dalam menyelesaikan permasalahan pemilihan smartphone khususnya untuk menunjang kegiatan akademis. Adapun program aplikasi yang dipakai pada penelitian kali ini adalah menggunakan program Microsoft Excel dan BWM Solver yakni fitur tambahan pada Microsoft Excel.

\section{TINJAUAN PUSTAKA}

\subsection{Teknologi Informasi dan Komunikasi}

TIK mencakup dua aspek, yaitu teknologi informasi dan teknologi komunikasi. Teknologi informasi, mencakup berbagai hal yang berkaitan dengan proses, penggunaan sebagai alat bantu, penanganan, dan manajemen informasi. Sementara itu, teknologi komunikasi mencakup segala sesuatu yang berkaitan dengan penggunaan alat bantu untuk memproses dan menyampaikan data dari satu perangkat ke perangkat yang lain. Menurut Munir (2009), TIK secara umum merangkum keseluruhan aspek yang berkaitan dengan mesin (komputer dan telekomunikasi) dan metode yang diterapkan untuk mengumpulkan, menyimpan, dan menyampaikan suatu informasi.

Pemanfaatan TIK membuka peluang kepada aspek pembelajaran untuk mengakses materi pembelajaran berupa media interaktif (Munir, 2009). Dunia pendidikan memanfaatkan kemajuan TIK sebagai sarana menyediakan seluruh informasi yang terkait dengan pendidikan. Sebab, kemajuan teknologi memberikan kemudahan dalam mengoperasikan kegiatan pembelajaran, serta dapat menaikkan kredibilitas dan produktivitas pengelolaan pendidikan.

\subsection{Smartphone}

Eriksson (2017) mendefinisikan smartphone sebagai telepon genggam dengan tampilan layar sentuh yang memungkinkan akses ke layanan berbasis internet tingkat lanut dan mampu melakukan banyak fungsi dari komputer, yakni memiliki sistem operasi yang dapat mengunduh serta menjalankan beragam aplikasi termasuk aplikasi yang dibuat oleh pengembang pihak ketiga.

\subsection{Multi Criteria Decision Making}

Menurut Artana (2009), Multi Criteria Decision Making (MCDM) merupakan suatu metode pengambilan keputusan yang didasarkan atas teori, proses dan metode analitik yang melibatkan ketidakpastian, dinamika dan aspek kriteria jamak. Tujuan akhir yang ingin dicapai menggunakan metode pengambilan keputusan MCDM adalah terpilihnya alternatif terbaik diantara alternatif lain berdasarkan pertimbangan kecenderungan bobot kriteria. 


\subsection{Best Worst Method}

Best-Worst Method (BWM) adalah metode MCDM baru yang dikembangkan oleh Dr. Jafar Rezaei pada tahun 2015. BWM menggunakan dua vektor perbandingan berpasangan dalam menentukan bobot ktiteria, pertama adalah yang terbaik seperti paling diinginkan atau paling penting dari kriteria lainnya dan yang kedua adalah yang terburuk seperti paling tidak diinginkan atau paling tidak penting dari kriteria lainnya (Razaei, 2015, 2016).

Bobot optimal untuk tiap kriteria yakni untuk setiap pasangan perbandingan bobot kriteria terbaik terhadap kriteria lain yakni dilambangkan dengan $w_{\mathrm{B}} / w_{\mathrm{j}}$ adalah sama dengan preferensi yang ditentukan oleh pengambil keputusan dari kriteria terbaik terhadap kriteria-kriteria lain yang dilambangkan dengan $a_{\mathrm{Bj}}$ dan preferensi kriteria lain terhadap kriteria terburuk dilambangkan dengan $a_{j w}$. Formulasi untuk mencari bobot optimal dimodelkan menjadi sebagai berikut.

$$
\begin{aligned}
& w_{B} / w_{j}=a_{B j} \text { dan } w_{j} / w_{w}=a_{j w} \\
& \min \max _{j}\left\{\left|\frac{w_{B}}{w_{j}}-a_{B j}\right|,\left|\frac{w_{B}}{w_{j}}-a_{B j}\right|\right\}
\end{aligned}
$$

Sedemikian sehingga jumlah seluruh bobot kriteria adalah sama dengan satu $\left(\sum_{j} w_{j}=1\right)$ dan bobot tiap kriteria mempunyai besaran lebih dari atau sama dengan nol $\left(w_{j} \geq 0\right)$ untuk semua $j$. Model (1) kemudian dikonversikan menjadi model linier BWM sebagai berikut.

min $\xi^{L}$ sedemikian sehingga

$\left|w_{B}-a_{B j} w_{j}\right| \leq \xi^{L}$, untuk semuaj

$\left|w_{j}-a_{j w} w_{w}\right| \leq \xi^{L}$, untuk semua $j$

$\sum_{j} w_{j}=1$

$w_{j} \geq 0$, untuk semuaj

Pemecahan dari model (2) sebagai model linier memiliki solusi $\left(w_{1}{ }^{*}, w_{2}{ }^{*}, \ldots w_{\mathrm{n}}{ }^{*}\right) . \xi^{L}$ dipertimbangkan sebagai indikator yang baik dari tingkat konsistensi pada perbandingan (Rezaei, 2015, 2016). Penyelesaian model (2) dipermudah dengan BWM Solver yang telah dikembangkan pada Microsoft Excel. Adapun perhitungan manual untuk menyelesaikan model (2) dapat dilakukan dengan pendekatan Simplex Linier Programming.

Perhitungan dari BWM sepenuhnya konsisten ketika $a_{\mathrm{Bj}} \mathrm{x} a_{\mathrm{jW}}=a_{\mathrm{BW}}$. Karena kemungkinan hasil perhitungan tidak memiliki konsistensi penuh, peneliti dapat menghitung tingkat konsistensi menggunakan indeks yang kuat yang disebut rasio konsistensi

$$
\text { Rasio Konsistensi }=\frac{\xi^{*}}{\text { Indeks konsistensi }}
$$

Rasio konsistensi (RK) mempunyai elemen yakni antara 0 sampai dengan 1. Semakin rendah RK yakni mendekati nilai 0 , semakin konsisten perbandingannya sehingga semakin dapat diandalkan. $\mathrm{RK} \leq 0,25$ dianggap sebagai tingkat konsistensi yang sangat tinggi. Dengan tabel Indeks Konsistensi :

Tabel 1. Indeks Konsistensi

\begin{tabular}{llllllllll}
\hline \multicolumn{1}{c}{$a_{B W}$} & 1 & 2 & 3 & 4 & 5 & 6 & 7 & 8 & 9 \\
\hline $\begin{array}{l}\text { Indeks } \\
\text { konsistensi } \\
(\max \xi)\end{array}$ & 0.00 & 0.44 & 1.00 & 1.63 & 2.30 & 3.00 & 3.73 & 4.47 & 5.23 \\
\hline
\end{tabular}




\subsection{Analytical Hierarchy Process}

\subsubsection{Pengertian Analytical Hie rarchy Process}

AHP didefinisikan sebagai metode yang digunakan untuk memecahkan permasalahan yang kompleks dan tidak terstruktur kemudian mengelompokkan elemen-elemen permasalahan ke dalam suatu susunan hierarki. Hierarki yang telah dirumuskan kemudian dilakukan penilaian numerik sebagai bentuk kecondongan perseorangan dalam melakukan perbandingan antar alternatif sehingga hasil akhir yang didapat adalah nilai prioritas tertinggi sebagai alternatif terbaik (Saaty, 1990).

Langkah-langkah pengolahan data menggunakan metode pengambilan keputusan AHP adalah sebagai berikut :

1. Menyusun struktur hirarki

2. Membuat matriks perbandingan berpasangan

3. Menghitung bobot kriteria

4. Menguji nilai konsistensi matriks berpasangan

5. Mengurutkan alternatif berdasarkan bobot yang didapat

Uji konsistensi dirumuskan sebagai berikut :

$$
\begin{aligned}
& \lambda_{\text {max }}=\frac{\text { Nilai Jumlah Tertimbang }(N J T)}{\text { Bobot Kriteria }(B K)} \\
& \text { Indeks Konsistensi }(I K)=\frac{\lambda_{\max }-n}{n-1} \\
& \text { Rasio Konsistensi }(R K)=\frac{I K}{R I} \\
& n=\text { jumlah kriteria yang digunakan }
\end{aligned}
$$

Dengan Nilai Random Index :

Tabel 2. Nilai Random Index

\begin{tabular}{lcccccccc}
\hline Orde matriks & 1 & 2 & 3 & 4 & 5 & 6 & 7 & 8 \\
\hline RI & 0.00 & 0.00 & 0.58 & 0.90 & 1.12 & 1.24 & 1.32 & 1.41 \\
\hline Orde Matriks & 9 & 10 & 11 & 12 & 13 & 14 & 15 \\
\hline RI & 1.45 & 1.49 & 1.51 & 1.48 & 1.56 & 1.57 & 1.59 \\
\hline
\end{tabular}

\subsubsection{Pengembangan AHP}

Perbandingan berpasangan yang dilakukan terhadap kriteria maupun alternatif tidak selalu hal-hal yang bersifat subjektif, ada kalanya nilai tiap kriteria sudah diketahui sebelumnya. Oleh karena itu, peneliti melakukan pengembangan terhadap metode AHP khususnya pada kasus perbandingan berpasangan antar kriteria maupun alternatif yang nilai kriterianya sudah diketahui untuk menghindari bias dalam proses pembobotan.

Tabel 3. Rentang Nilai dan Tingkatan Bobot

\begin{tabular}{cc}
\hline Kriteria & Tingkatan Bobot \\
\hline Rentang nilai tertinggi & 5 \\
Rentang nilai kedua tertinggi & 4 \\
Rentang nilai pertengahan & 3 \\
Rentang nilai kedua terendah & 2 \\
Rentang nilai terendah & 1 \\
\hline
\end{tabular}

Tabel rentang nilai dan tingkatan bobot digunakan untuk menentukan tingkatan bobot perbandingan berpasangan suatu kriteria. Tingkatan bobot dibagi menjadi lima tingkatan merujuk kepada Skala Matriks Perbandingan dengan lima tingkatan bobot tanpa memasukkan grey area. Tingkatan bobot yang didapat kemudian dikonversikan menjadi bobot dengan terlebih dahulu dilakukan perhitungan selisis tingkatan bobot dengan tabel sebagai berikut : 
Tabel 4. Selisih Tingkatan Bobot

\begin{tabular}{clr}
\hline Selisih Tingkatan Bobot & keterangan perbandingan selisih tingkatan bobot & Bobot \\
\hline 4 & elemen yang satu mutlak lebih penting & 9 \\
3 & elemen yang satu sangat jelas lebih penting & 7 \\
2 & elemen yang satu jelas lebih penting & 5 \\
1 & elemen yang satu sedikit lebih penting & 3 \\
0 & elemen yang satu sama pentingnya dibandingkan elemen yang lain & 1 \\
-1 & elemen yang satu sedikit tidak lebih penting & $1 / 3$ \\
-2 & elemen yang satu jelas tidak lebih penting & $1 / 5$ \\
-3 & elemen yang satu sangat jelas tidak lebih penting & $1 / 7$ \\
-4 & elemen yang satu mutlak tidak lebih penting & $1 / 9$ \\
\hline
\end{tabular}

Hasil perhitungan Selisih Tingkatan Bobot selanjutnya dikonversikan menjadi nilai bobot yang akan digunakan dalam perhitungan perbandingan berpasangan sebagaimana proses perhitungan bobot dari metode AHP.

\subsection{Metode Delphi}

Metode delphi adalah proses yang dilakukan dalam kelompok untuk mensurvei dan mengumpulkan pendapat dari para ahli terkait topik tertentu atau biasa disebut sebagai pakar. Adapun para pakar tersebut tidak dipertemukan secara langsung (tatap muka), dan identitas dari masing-masing pakar disembunyikan sehingga setiap pakar tidak mengetahui identitas pakar yang lain. Hal ini bertujuan untuk menghindari adanya dominasi pakar lain dan dapat meminimalkan pendapat yang bias. Dalkey dan Helmer (1962) membuktikan bahwa secara statistik, metode Delphi ternyata cenderung, tidak hanya tercapai konvergen, tapi juga konvergen kearah yang benar.

\section{METODE PENELITIAN}

\subsection{Sumber Data}

Berbagai sumber data yang akan dimanfaatkan dalam penelitian ini sebagai berikut :

1. Data Primer

Sumber data primer yang digunakan dalam penelitian ini adalah hasil angket terhadap beberapa responden yang dianggap sebagai pakar diantaranya :

a. Pihak merek smartphone yang digunakan sebagai objek penelitian yakni Samsung, Oppo, Xiaomi Apple dan Realme

b. Pihak Akademisi

c. Pihak peserta didik dan tenaga kependidikan

2. Data Sekunder

Sumber data sekunder yang digunakan adalah sumber tertulis berupa buku dan jurnal serta laman internet terkait tipe dan spesifikasi smartphone.

\subsection{Metode Analisis}

Software yang digunakan pada penelitian kali ini adalah Ms. Excel 2019 dan BWM Solvers dengan tahapan analisis sebagai berikut :

1. Identifikasi kriteria smartphone

2. Validasi pakar menggunakan metode delphi

3. Penentuan alternatif smartphone

4. Penentuan bobot kriteria dan alternatif

5. Perhitungan bobot optimal kriteria menggunakan metode BWM 
6. Perhitungan bobot optimal alternatif berdasarkan kriteria menggunakan pengembangan metode AHP

7. Analisis pengurutan prioritas alternatif menggunakan perpaduan metode BWM dan Pengembangan AHP

\section{HASIL DAN PEMB AHASAN}

\subsection{Penenentuan kriteria}

Penentuan kriteria yang dimaksud dalam penelitian kali ini adalah kriteria berupa spesifikasi umum yang terdapat pada smartphone dan bukan merupakan fitur spesifik yang dimiliki oleh smartphone.

\begin{tabular}{lll}
\multicolumn{2}{c}{ Tabel 5. Kriteria Smartphone } \\
\hline KRITERIA & Deskripsi & Sumber \\
\hline Harga & Biaya yang dikeluarkan untuk memiliki barang & Medcom.id \\
Kamera & Fitur yang digunakan untuk menangkap gambar & Medcom.id \\
Baterai & Komponen yang berfungsi pada daya tahan & Medcom.id \\
Chipset & Komponen yang berpengaruh pada kinerja & Gesindo.sindonews.com \\
Ukuran Layar & perangkat & Medcom.id \\
RAM & Ukuran Panjang x Lebar Perangkat & Medcom.id \\
ROM/Internal & Komponen ruang penyimpanan aplikasi yang & Medcom.id \\
Resolusi Layar & Kompontif & Medcom.id \\
\hline
\end{tabular}

\subsection{Validasi Kriteria}

Proses validasi kriteria dilakukan menggunakan metode delphi untuk menentukan, menambah ataupun mengurangi kriteria yang akan digunakan pada penelitian kali ini. Pemvalidasian kuesioner ini dilakukan oleh lima orang pakar dari pihak brand yang paham akan spesifikasi smartphone, satu orang pakar dari pihak akademisi, satu orang dari pihak mahasiswa dan satu orang dari pihak tenaga kependidikan.

Hasil validasi yang telah dilakukan oleh para pakar dan pihak terkait adalah para pakar dan pihak terkait menyetujui semua kriteria yang diajukan untuk dilakukan penelitian lebih lanjut sehingga tidak ada penambahan maupun pengurangan pada kriteria yang diajukan.

\begin{tabular}{|c|c|c|}
\hline $\mathrm{Kr}$ & la 1erpint & setes s s \\
\hline $\mathrm{NO}$ & KRITERIA & Simbol \\
\hline 1 & Harga & $\mathrm{Cl}$ \\
\hline 2 & Kamera & $\mathrm{C} 2$ \\
\hline 3 & Baterai & $\mathrm{C} 3$ \\
\hline 4 & Chipset & $\mathrm{C} 4$ \\
\hline 5 & Ukuran Layar & C5 \\
\hline 6 & RAM & C6 \\
\hline 7 & ROM/Internal & $\mathrm{C} 7$ \\
\hline 8 & Resolusi Layar & C8 \\
\hline
\end{tabular}

\subsection{Penentuan Alternatif Smartphone}

Penentuan alternatif smartphone yang akan digunakan dalam penelitian ini dilakukan oleh penulis. Alternatif smartphone yang digunakan berasal dari 5 brand smartphone yang dijadikan bahan penelitian dan dari masing-masing tingkatan kelas. Berikut adalah tabel daftar alternatif smartphone : 


\begin{tabular}{|c|c|c|c|}
\hline No & $\begin{array}{c}\text { Nama } \\
\text { Produk }\end{array}$ & Brand & Simbol \\
\hline 1 & $\begin{array}{c}\text { Xiaomi } \\
\text { Redmi } \\
5 \mathrm{~A}\end{array}$ & Xiaomi & A1 \\
\hline 2 & $\begin{array}{l}\text { Redmi } \\
\text { Note } 9\end{array}$ & Xiaomi & A2 \\
\hline 3 & $\begin{array}{c}\text { Mi } 10 \\
\text { Ultra }\end{array}$ & Xiaomi & A3 \\
\hline 4 & $\mathrm{C} 1$ & Realme & A4 \\
\hline 5 & Q2 & Realme & A5 \\
\hline 6 & V5 & Realme & A6 \\
\hline 7 & A5 & Oppo & A7 \\
\hline 8 & Find $\mathrm{X}$ & Oppo & A8 \\
\hline 9 & Find $\mathrm{X} 2$ & Oppo & A9 \\
\hline 10 & $\begin{array}{c}\text { Galaxy } \\
\text { M21 }\end{array}$ & Samsung & A10 \\
\hline 11 & $\begin{array}{c}\text { Galaxy } \\
\text { M51 } \\
\text { Galaxy }\end{array}$ & Samsung & A11 \\
\hline 12 & $\begin{array}{c}\text { Note } 20 \\
\text { Ultra }\end{array}$ & Samsung & A12 \\
\hline 13 & Iphone 7 & Apple & A13 \\
\hline 14 & Iphone 8 & Apple & A14 \\
\hline 15 & Iphone 12 & Apple & A15 \\
\hline
\end{tabular}

\subsection{Pembobotan Krite ria dan Alternatif}

Pembobotan kriteria mengikuti kaidah metode pengambilan keputusan BWM yakni menentukan kriteria terbaik dan terburuk dari daftar kriteria yang ada. Selanjutnya dilakukan penilaian preferensi kriteria terbaik terhadap kriteria lain (Best to Others) dan penilaian preferensi kriteria-kriteria lain terhadap kriteria terburuk (Others to Worst). Hasil penentuan kriteria terbaik dan kriteria terburuk oleh partisipan adalah sebagai berikut:

Tabel 8. Kriteria Terbaik dan Terburuk

\begin{tabular}{lllllllll}
\hline \multirow{2}{*}{ Kriteria } & \multicolumn{9}{c}{ Partisipan } \\
\cline { 2 - 9 } & P1 & P2 & P3 & P4 & P5 & P6 & P7 & P8 \\
\hline Best & C6 & C6 & C6 & C6 & C3 & C6 & C6 & C6 \\
Worst & C8 & C5 & C5 & C5 & C2 & C5 & C5 & C2 \\
\hline
\end{tabular}

Rata-rata partisipan pengisian angket menganggap kriteria C6 (kriteria RAM) sebagai kriteria terbaik, sementara itu kriteria C8 (Resolusi Layar) maupun C5 (Ukuran Layar) bergantian dipilih menjadi kriteria terburuk dalam menjadi pertimbangan yakni membeli smartphone terbaik penunjang kegiatan akademik.

Selanjutnya, pembobotan alternatif berdasarkan kriteria dilakukan menggunakan kaidah metode pengambilan keputusan AHP yang sudah dilakukan pengembangan. Berikut adalah tabel tingkatan bobot kriteria dan tabel selisih tingkatan bobot untuk pembobotan alternatif :

Tabel 9. Tingkatan Bobot Tiap Kriteria

\begin{tabular}{|c|c|c|c|}
\hline Range harga & Tingkatan Bobot & Ukuran Layar & $\begin{array}{c}\text { Tingkatan } \\
\text { Bobot }\end{array}$ \\
\hline$\leq \mathrm{Rp} 2$ Juta & 5 & $>6$ inch & 5 \\
\hline Rp 2 Juta s.d. $\leq$ Rp 4 Juta & 4 & 5 inch s.d. $\leq 6$ inch & 4 \\
\hline Rp 4 Juta s.d. $\leq$ Rp 6 Juta & 3 & 4 inch s.d. $\leq 5$ inch & 3 \\
\hline Rp 6 Juta s.d. Rp 8 Juta & 2 & 3 inch s.d. $\leq 4$ inch & 2 \\
\hline$>$ Rp 8 Juta & 1 & $\leq 3$ inch & 1 \\
\hline
\end{tabular}




\begin{tabular}{cc}
\hline Pixel Kamera & Tingkatan Bobot \\
\hline$>48 \mathrm{MP}$ & 5 \\
$13 \mathrm{MP}$ s.d. $\leq 48 \mathrm{MP}$ & 4 \\
$8 \mathrm{MP}$ s.d. $\leq 13 \mathrm{MP}$ & 3 \\
$5 \mathrm{MP}$ s.d. $\leq 8 \mathrm{MP}$ & 2 \\
$\leq 5 \mathrm{MP}$ & 1 \\
\hline
\end{tabular}

\begin{tabular}{cc}
\hline Ukuran Baterai & Tingkatan Bobot \\
\hline$>5000 \mathrm{mAh}$ & 5 \\
$4000 \mathrm{mAh}$ s.d. $\leq 5000 \mathrm{mAh}$ & 4 \\
$3000 \mathrm{mAh}$ s.d. $\leq 4000 \mathrm{mAh}$ & 3 \\
$2000 \mathrm{mAh}$ s.d. $\leq 3000 \mathrm{mAh}$ & 2 \\
$\leq 2000 \mathrm{mAh}$ & 1 \\
\hline
\end{tabular}

\begin{tabular}{cc}
\hline $\begin{array}{c}\text { Daftar Chipset (atau yang setara } \\
\text { denganya) }\end{array}$ & Tingkatan Bobot \\
\hline Snapdragon 800 series & 5 \\
Snapdragon 700 series & 4 \\
Snapdragon 600 series & 3 \\
Snapdragon 400 series & 2 \\
Snapdragon 200 series & 1 \\
\hline
\end{tabular}

\begin{tabular}{cc}
\hline Ukuran RAM & $\begin{array}{c}\text { Tingkatan } \\
\text { Bobot }\end{array}$ \\
\hline$>8$ GB & 5 \\
6 GB s.d. $\leq 8$ GB & 4 \\
4 GB s.d. $\leq 6$ GB & 3 \\
2 GB s.d. $\leq 4$ GB & 2 \\
$\leq 2 \mathrm{~GB}$ & 1 \\
\hline & \\
\hline Besar ROM & Tingkatan \\
& Bobot \\
\hline 256 GB & 5 \\
128 GB & 4 \\
64 GB & 3 \\
32 GB & 2 \\
16 GB & 1 \\
\hline & \\
\hline Resolusi Layar & Tingkatan \\
\hline 2K UHD & Bobot \\
FHD+ / QHD & 5 \\
1080p FHD & 3 \\
$720 p$ HD & 2 \\
qHD & 1
\end{tabular}

\subsection{Perhitungan Bobot Optimal Kriteria}

Perhitungan bobot optimal kriteria menggunakan metode BWM sebagai berikut : Tabel 10. Bobot Kriteria dan Nilai Ksi

\begin{tabular}{|c|c|c|c|c|c|c|c|c|c|c|}
\hline $\begin{array}{c}\text { Rekapitulasi } \\
\text { Hasil } \\
\text { Pembobotan }\end{array}$ & Harga & Kamera & Baterai & Chipset & $\begin{array}{c}\text { Ukuran } \\
\text { Layar }\end{array}$ & RAM & ROM/Internal & $\begin{array}{c}\text { Resolusi } \\
\text { Layar }\end{array}$ & Jumlah & Ksi \\
\hline $\mathrm{P} 1$ & 0,063 & 0,148 & 0,148 & 0,089 & 0,063 & 0,367 & 0,089 & 0,032 & 1 & 0,077263 \\
\hline $\mathrm{P} 2$ & 0,075 & 0,126 & 0,094 & 0,126 & 0,027 & 0,310 & 0,189 & 0,054 & 1 & 0,067325 \\
\hline P3 & 0,146 & 0,052 & 0,122 & 0,122 & 0,024 & 0,292 & 0,122 & 0,122 & 1 & 0,072917 \\
\hline $\mathrm{P} 4$ & 0,106 & 0,084 & 0,141 & 0,106 & 0,028 & 0,335 & 0,141 & 0,060 & 1 & 0,087205 \\
\hline P5 & 0,099 & 0,038 & 0,401 & 0,082 & 0,099 & 0,099 & 0,082 & 0,099 & 1 & 0,093407 \\
\hline P6 & 0,127 & 0,127 & 0,076 & 0,127 & 0,028 & 0,314 & 0,127 & 0,076 & 1 & 0,066079 \\
\hline P7 & 0,170 & 0,068 & 0,113 & 0,113 & 0,027 & 0,291 & 0,170 & 0,048 & 1 & 0,048491 \\
\hline P8 & 0,077 & 0,028 & 0,128 & 0,128 & 0,077 & 0,317 & 0,192 & 0,055 & 1 & 0,066683 \\
\hline
\end{tabular}

Dari hasil di atas di dapat nilai Rasio Konsistensi (Ksi) untuk semua perhitungan < 0,1 , hal ini menunjukkan pembobotan kriteria konsisten. Bobot optimal yang telah didapatkan selanjutnya akan dilakukan perhitungan rata-rata untuk mendapatkan hasil akhir berupa vector bobot tunggal.

Tabel 11. Pengurutan Kriteria

\begin{tabular}{cccc}
\hline $\begin{array}{c}\text { Urutan } \\
\text { Bobot } \\
\text { Optimal }\end{array}$ & Kriteria & Simbol & Bobot Rata-Rata \\
\hline 1 & RAM & C6 & 0,290 \\
2 & Baterai & C3 & 0,153 \\
3 & ROM/Internal & C7 & 0,139 \\
4 & Chipset & C4 & 0,111 \\
5 & Harga & C1 & 0,108 \\
6 & Kamera & C2 & 0,084 \\
7 & Resolusi Layar & C8 & 0,068 \\
8 & Ukuran Layar & C5 & 0,047 \\
\hline
\end{tabular}

Berdasarkan Tabel 11 didapat kriteria RAM memiliki bobot paling besar dibandingkan dengan kriteria lainnya dan kriteria Ukuran Layar memiliki bobot paling kecil dibandingkan kriteria lainnya. Hal ini menunjukkan bahwa dalam membeli smartphone khususnya untuk keperluan 
penunjang kegiatan akademik, kriteria RAM menjadi prioritas yang dijadikan pertimbangan sedangkan kriteria Ukuran Layar kurang menjadi prioritas pertimbangan dibandingkan kriteria lain.

\subsection{Pe rhitungan Bobot Optimal Alternatif Berdas arkan Kriteria}

Perhitungan bobot optimal alternatif berdasarkan kriteria menggunakan Pengembangan metode AHP.

Tabel 2. Bobot Alternatif dan Rasio Konsistensi Tiap Kriteria

\begin{tabular}{ccccccccc}
\hline $\begin{array}{c}\text { Bobot } \\
\text { Alternatif }\end{array}$ & Harga & Kamera & Baterai & Chipset & $\begin{array}{c}\text { Ukuran } \\
\text { Layar }\end{array}$ & RAM & ROM/Internal & $\begin{array}{c}\text { Resolusi } \\
\text { Layar }\end{array}$ \\
\hline A1 & 0,148 & 0,026 & 0,017 & 0,013 & 0,016 & 0,014 & 0,010 & 0,015 \\
A2 & 0,075 & 0,072 & 0,155 & 0,023 & 0,079 & 0,031 & 0,032 & 0,030 \\
A3 & 0,012 & 0,072 & 0,068 & 0,125 & 0,079 & 0,129 & 0,072 & 0,065 \\
A4 & 0,148 & 0,026 & 0,031 & 0,013 & 0,079 & 0,014 & 0,016 & 0,065 \\
A5 & 0,040 & 0,072 & 0,068 & 0,050 & 0,079 & 0,031 & 0,072 & 0,065 \\
A6 & 0,012 & 0,072 & 0,068 & 0,050 & 0,079 & 0,066 & 0,072 & 0,065 \\
A7 & 0,148 & 0,026 & 0,068 & 0,023 & 0,079 & 0,031 & 0,032 & 0,015 \\
A8 & 0,040 & 0,072 & 0,031 & 0,125 & 0,079 & 0,129 & 0,158 & 0,065 \\
A9 & 0,012 & 0,072 & 0,068 & 0,125 & 0,079 & 0,233 & 0,158 & 0,153 \\
A10 & 0,148 & 0,072 & 0,155 & 0,050 & 0,079 & 0,031 & 0,032 & 0,065 \\
A11 & 0,040 & 0,171 & 0,155 & 0,050 & 0,079 & 0,066 & 0,072 & 0,065 \\
A12 & 0,012 & 0,171 & 0,068 & 0,125 & 0,079 & 0,129 & 0,158 & 0,153 \\
A13 & 0,075 & 0,026 & 0,010 & 0,050 & 0,016 & 0,014 & 0,016 & 0,015 \\
A14 & 0,075 & 0,026 & 0,010 & 0,050 & 0,016 & 0,014 & 0,032 & 0,015 \\
A15 & 0,012 & 0,026 & 0,031 & 0,125 & 0,079 & 0,066 & 0,072 & 0,153 \\
CR & 0,030 & 0,006 & 0,025 & 0,016 & 0,000 & 0,026 & 0,024 & 0,015 \\
\hline
\end{tabular}

Dari hasil di atas, Rasio Konsistensi (RK) dari tiap alternatif menunjukkan nilai kurang dari 0,1. Hal ini menunjukkan perhitungan bobot optimal alternatif berdasarkan kriteria dapat diterima karena tingkat konsistensi perbandingan yang baik dan perbandingan berpasangan dapat dipertanggunjawabkan.

\subsection{Perhitungan Bobot Optimal Final dari Alternatif}

Hasil dari perhitungan bobot optimal kriteria akan dikalikan dengan hasil perhitungan bobot optimal alternatif berdasarkan kriteria untuk mencari bobot optimal final tiap alternatif kemudian diurutkan.

Tabel . Bobot Optimal Final Tiap Alternatif

\begin{tabular}{|c|c|c|c|c|}
\hline Urutan & $\begin{array}{l}\text { Nama } \\
\text { Produk }\end{array}$ & Brand & Simbol & $\begin{array}{c}\text { Jumlah } \\
\text { Bobot }\end{array}$ \\
\hline 1 & $\begin{array}{c}\text { Find } \\
\text { X2 }\end{array}$ & Oppo & A9 & 0,1353 \\
\hline 2 & $\begin{array}{c}\text { Galaxy } \\
\text { Note } \\
20 \\
\text { Ultra }\end{array}$ & Samsung & A12 & 0,1133 \\
\hline 3 & Find $\mathrm{X}$ & Oppo & A8 & 0,0964 \\
\hline 4 & $\begin{array}{c}\text { Mi } 10 \\
\text { Ultra }\end{array}$ & Xiaomi & A3 & 0,0870 \\
\hline 5 & $\begin{array}{c}\text { Galaxy } \\
\text { M51 }\end{array}$ & Samsung & A11 & 0,0852 \\
\hline 6 & $\begin{array}{c}\text { Galaxy } \\
\text { M21 }\end{array}$ & Samsung & A10 & 0,0729 \\
\hline 7 & $\begin{array}{c}\text { Iphone } \\
12\end{array}$ & Apple & A15 & 0,0654 \\
\hline 8 & V5 & Realme & A6 & 0,0605 \\
\hline 9 & $\begin{array}{l}\text { Redmi } \\
\text { Note } 9\end{array}$ & Xiaomi & $\mathrm{A} 2$ & 0,0596 \\
\hline 10 & Q2 & Realme & A5 & 0,0535 \\
\hline
\end{tabular}




\begin{tabular}{ccccc}
11 & A5 & Oppo & A7 & 0,0493 \\
12 & C1 & Realme & A4 & 0,0388 \\
& $\begin{array}{c}\text { Xiaomi } \\
\text { Redmi } \\
5 \text { A }\end{array}$ & Xiaomi & A1 & 0,0295 \\
& $\begin{array}{c}\text { Iphone } \\
8\end{array}$ & Apple & A14 & 0,0278 \\
14 & $\begin{array}{c}\text { Iphone } \\
7\end{array}$ & Apple & A13 & 0,0256 \\
\hline
\end{tabular}

Dari tabel di atas didapatkan bahwa alternatif dengan nilai bobot tertinggi adalah A9 yakni Oppo Find X2 dengan akumulasi nilai bobot optimal final sebesar 0,1353. Sementara itu, Apple Iphone 7 menjadi urutan terakhir prioritas alternatif dengan nilai bobot optimal final sebesar 0,0256. Hal ini menunjukkan bahwa Oppo Find X2 menjadi pilihan smartphone terbaik dalam memenuhi kebutuhan penunjang akademik berdasarkan bobot kriteria dan spesifikasi yang tersemat padanya.

\section{KESIMPULAN}

Kesimpulan yang didapat dari hasil analisis dan pembahasan pada penelitian ini adalah sebagai berikut :

1. Metode pengambilan keputusan BWM dan AHP yang sudah dikembangkan memiliki beberapa kelebihan yakni metode BWM membuat perbandingan secara terstruktur dan metode AHP menghitung bobot dengan sturktur hierarki sehingga proses perhitungan rinci dari kriteria sampai sub-kriteria serta memperhitungkan validitas sampai dengan batas toleransi inkonsistensi. Hasil akhir yang didapat memberi kemudahan pengguna dalam memilih smartphone penunjang kegiatan akademis serta metode yang dipakai dapat menjadi alternatif metode pengambilan keputusan untuk permasalahan sejenis maupun permasalahan lainnya.

2. Hasil perhitungan bobot optimal kriteria yang didapat menggunakan metode BWM adalah kriteria RAM (C6) menjadi kriteria dengan nilai bobot tertinggi yakni 0,290 dan kriteria Ukuran Layar (C5) menjadi kriteria dengan nilai bobot terendah yakni 0,047. Hal ini menunjukkan bahwa kriteria RAM menjadi prioritas pertimbangan dan kriteria Ukuran Layar kurang menjai prioritas pertimbangan dalam memilih smartphone khususnya sebagai penunjang akademis.

3. Analisis dan pembahasan didapat bobot optimal final alternatif A9 atau Oppo Find X2 menjadi alternatif dengan nilai bobot terbesar yakni 0,1353 sedangkan alternatif A13 atau Apple Iphone 7 menjadi alternatif dengan nilai bobot terendah yakni 0,0256 .

\section{DAFTAR PUSTAKA}

Artana, K.B., 2009. Pengambilan Keputusan Kriteria Jamak (MCDM) untuk Pemilihan Lokasi Floating Storage and Regasification Unit (FSRU): Studi Kasus Suplai LNG dari Ladang Tangguh ke Bali. Jurnal Teknik Industri, 10(2), pp.97-111.

Barlian, E., 2016. Metodologi Penelitian Kualitatif \& Kuantitatif. Padang: Sukabina Press.

Budiman, H., 2017. Peran teknologi informasi dan komunikasi dalam pendidikan. Al-Tadzkiyyah: Jurnal Pendidikan Islam, 8(1), pp.31-43.

Dalkey, N. and Helmer, O., 1963. An experimental application of the Delphi method to the use of experts. Management science, 9(3), pp.458-467.

Dalkey, N.C., 1967. Delphi. California. The Rand Corporation. 
Dalkey, N.C., 1972. Studies In The Quality Of Life; Delphi And Decision-Making. California: Lexington Books.

Eriksson, F. 2017. Proposal For A Definition Of Smartphone. International Telecommunication Union (ITU), pp. 5-8.

Gunawan, I., 2013. Metodologi Penelitian Kualitatif. Bandung: Remaja Rosdakarya.

Gustina, D. and Mutiara, D., 2017. Sistem Penunjang Keputusan Pemilihan Router Mikrotik Dengan Menggunakan Metode AHP (Analitycal Hierarchy Process). Jurnal Ilmiah FIFO, 9(1), pp.6873.

Latifah, S., 2005. Prinsip-Prinsip Dasar Analytical Hierarchy Process. Jurnal Studi Kasus Fakultas Pertanian, Universitas Sumatera Utara (USU), Medan.

Ma'azer Al Fawareh, H. and Jusoh, S., 2017. The use and effects of smartphones in higher education. iJIM, 11(6), p.103.

Munir, D. and IT, M., 2009. Pembelajaran jarak jauh berbasis teknologi informasi dan komunikasi. Bandung: Alfabeta.

Pfeiffer, J. (1968). New look at education. Poughkeepsie, NY: Odyssey Press.

Pulkkinen, J., 2007. Cultural globalization and integration of ICT in education. Educational technology: Opportunities and challenges, pp.13-23.

Purw ati, D.D., 2017. Pengaruh Penggunaan Smartphone dalam Aktivitas Belajar Terhadap Prestasi Belajar Siswa Kelas VIII Di SMP Negeri 7 Kota Kediri Tahun Pelajaran 2016/2017 (Doctoral dissertation, IAIN Kediri).

Rahardjo, J., Yustina, R. and Stok, R.E., 2000. Penerapan Multi-Criteria Decision Making Dalam Pengambilan Keputusan Sistem Perawatan. Jurnal Teknik Industri, 2(1), pp.1-12.

Saaty, T.L., 1990. How to make a decision: the analytic hierarchy process. European journal of operational research, 48(1), pp.9-26.

Triantaphyllou, E., 2000. Multi-criteria decision making methods. In Multi-criteria decision making methods: A comparative study. Springer, pp. 5-21.

Triantaphyllou, E., Shu, B., Sanchez, S.N. and Ray, T., 1998. Multi-criteria decision making: an operations research approach. Encyclopedia of electrical and electronics engineering, 15(1998), pp.175-186.

Turoff, M. and Linstone, H.A., 2002. The Delphi method-techniques and applications. Boston: Addison-Wesley.

Wirdasari, D., 2009. Metode Simpleks dalam Program Linier. Jurnal Saintikom, 6(1), pp.276-285.

Yousuf, M.I., 2007. The Delphi technique. Essays in Education, 20(1), p.8. 